\begin{tabular}{|c|c|c|}
\hline & $\begin{array}{c}\text { Klinikal Sains } 8(1)(2020) \\
\text { JURNAL ANALIS KESEHATAN } \\
\text { KLINIKAL SAINS }\end{array}$ & KLINKALSANS \\
\hline $\begin{array}{l}\text { UNIVERSITAS } \\
\text { ABDURRAB }\end{array}$ & http://jurnal.univrab.ac.id/index.php/klinikal & 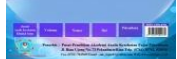 \\
\hline
\end{tabular}

\title{
IDENTIFIKASI BAKTERI RONGGA MULUT PEROKOK DAN BUKAN PEROKOK DI PEKANBARU
}

\author{
Titi Lasmini \\ Program Studi DIII Analis Kesehatan, Akademi Kesehatan John Paul II Pekanbaru \\ Jl. Permata 1, No. 32 Pekanbaru \\ Telp (0761) 563763 \\ Alamat e-mail : lasmini.titi@gmail.com
}

\begin{abstract}
Info Artikel
Abstrak

Sejarah Artikel:

bulnya berbagai masalah sesehatan salah satunya penyakit rongga mulut. Kondisi kesehatan mulut yang menurun akibat rokok tersebut dapat menurunkan jumlah bakteri flora normal rongga mulut dan meningkatkan jumlah bakteri potensial pathogen. Penelitian ini bertujuan untuk mengisolasi dan mengidentifikasi jenis-jenis bakteri pada rongga

Diterima Maret 2020

Disetujui Maret 2020

Dipublikasikan Juni 2020 mulut perokok dan bukan perokok di Pekanbaru. Penelitian ini dilakukan dengan isolasi bakteri pada medium MSA dan MacConkey, purifikasi, dan uji reaksi biokimia. Hasil penelitian menunjukkan bahwa jumlah isolat bakteri dari sampel rongga mulut perokok lebih tinggi (37 isolat), dibanding bukan perokok (26 isolat). Coagulase Negative Staphylococcus (27,03\%), dan Aggregatibacter sp. (21,62\%)

Keywords: lebih sering diisolasi dari rongga mulut perokok, sedangkan Coagulase Negative Staphylococcus (30,77\%), Pseudomonas sp. (26,92\%), dan Klebsiella sp. (19,23\%) lebih sering diisolasi dari rongga mulut bukan perokok.
\end{abstract}

Bakteri, Rongga mulut, Perokok

Kata Kunci: Bakteri, Rongga Mulut, Perokok

\begin{abstract}
Smoking is one of the causes of various health problems, one of which is oral disease. Poor oral health conditions due to smoking can reduce the number of normal flora of the oral cavity and increase the number of potential pathogenic bacteria. This research aims to isolate and identify the bacteria in the oral cavity of smokers and nonsmokers in Pekanbaru. This research was carried out with bacterial isolation on MSA and MacConkey medium, purification, and biochemical reaction tests. The results showed that the number of bacterial isolates from oral cavity of smokers were higher (37 isolates) than nonsmokers (26 isolates). Coagulase Negative Staphylococcus (27,03\%) and Aggregatibacter sp. (21,62\%) were frequently isolated from smokers, while Coagulase Negative Staphylococcus (30,77\%), Pseudomonas sp. (26,92\%), and Klebsiella sp. (19,23\%) were frequently isolated from nonsmokers.
\end{abstract}

Keyword : Bacteria, Oral Cavity, Smokers

(C) 2020 Universitas Abdurrab 


\footnotetext{
Alamat korespondensi:

J1. Permata 1, No.32 Pekanbaru

E-mail: lasmini.titi@gmail.com
}

ISSN 2338-4921

\section{PENDAHULUAN}

Laporan Global Adult Tobacco Survey (GATS) pada tahun 2011 menyebutkan bahwa di Indonesia $67 \%$ penduduk laki-laki dan 2,7\% perempuan merupakan konsumen rokok, dan pada laporan tahun 2012 World Health Organization (WHO) menempatkan Indonesia diperingkat ketiga dalam hal konsumsi rokok terbesar setelah Cina dan India (WHO, 2011). Kebiasaan merokok merupakan salah satu penyebab timbulnya penyakit rongga mulut seperti kanker mulut, penyakit periodontal, dan karies gigi (Warnakulasuriya et al., 2010).

Rongga mulut merupakan organ yang paling mudah terpapar efek rokok karena bersinggungan langsung dengan asap rokok dan berdampak pada munculnya berbagai gangguan patologis rongga mulut dan mempengaruhi komunitas bakteri didalamnya (Yu et al., 2017). Kandungan Tar pada rokok dapat mengendap pada permukaan gigi sehingga mengakibatkan permukaan gigi menjadi kasar dan mempermudah perlekatan bakteri. Selain itu asap rokok memiliki suhu cukup panas sehingga mengakibatkan rongga mulut menjadi lebih kering dan anaerob. Kondisi ini memberikan lingkungan yang sesuai untuk pertumbuhan bakteri anaerob dan mempercepat terbentuknya plak pada gigi (Fitri and Hidayati, 2012). Kondisi kesehatan mulut yang menurun akibat rokok tersebut dapat menurunkan jumlah bakteri flora normal rongga mulut dan meningkatkan jumlah bakteri potensial pathogen (Charlson et al., 2010).

Berbagai spesies bakteri dapat ditemukan pada lokasi berbeda di dalam rongga mulut seperti mukosa mulut, saliva, permukaan gigi, lidah, pipi, langit-langit dan bagian lainnya (Dewhirst et al., 2010). Penelitian sebelumnya menemukan bahwa jumlah bakteri pathogen menjadi lebih banyak pada perokok. Bakteri pathogen dijumpai pada 43\% perokok, dan pada $20 \%$ non perokok (Yetkin et al., 2010). Bakteri yang telah berhasil diidentifikasi pada mulut perokok diantaranya adalah Streptococcus, Haemophillus, Campylobacter, Pseudomonas, Neisseria, Lactobacillus, Fusobacterium, dan Propionibacterium. Sedangkan pada bukan perokok ditemui Streptococcus, Neisseria, Veillonella dan Selenomonas (Kumar et al., 2011).

Diperkirakan terdapat kurang lebih 700 spesies bakteri terdapat dalam rongga mulut, dan 50\% diantaranya belum berhasil dikultur disebabkan kebutuhannya akan nutrient tertentu, sensitivitasnya terhadap oksigen, dan ketergantungan akan mikroorganisme lainnya (Arweiler and Netuschil, 2016). Oleh sebab itu perlu dilakukan penelitian mengenai identifikasi bakteri pada rongga mulut terutama untuk mengetahui perbedaan jenis flora pada rongga mulut perokok dan bukan perokok. 


\section{METODE}

Penelitian dilaksanakan dengan menggunakan metode isolasi bakteri secara Spread plate. Bakteri dikultur dan dibiakkan dari sampel rongga mulut perokok dan bukan perokok pada media Mannitol Salt Agar dan MacConkey agar. Penelitian ini dilaksanakan pada bulan Januari - Mei 2019, bertempat di Laboratorium Bakteriologi Akademi Kesehatan John Paul II Pekanbaru.

Alat-alat yang digunakan dalam penelitian ini antara lain Botol sampel, alat-alat gelas, Pipet Mikro 100-1000 $\mu$ L, Inkubator, Oven, Otoklaf, Mikroskop, Vortex, Gelas Objek, Jarum Ose, Bunsen, Drigalski, Rak tabung. Bahan-bahan yang digunakan yaitu Sampel, Medium Mannitol Salt Agar (MSA), McConkey Agar (MC), Blood Agar Base, Triple Sugar Iron Agar (TSIA), Sulfur Indole Motility (SIM), Simmon Citrate (SC), Buffered Peptone Water (BPW), Indikator Bromothymol Blue (BTB), Reagen Kovac's, Reagen $\mathrm{H}_{2} \mathrm{O}_{2} 10 \%$, Reagen Pewarnaan Gram, Glukosa, Sukrosa, Laktosa, Maltosa, Mannitol, Larutan garam fisiologis 0,9\%.

\section{Prosedur Kerja}

\section{Subjek penelitian}

Penilitian ini menggunakan sampel air kumur dari perokok aktif dan bukan perokok yang memenuhi kriteria rentang usia remaja sampai dewasa serta tidak sedang mengonsumsi antibiotik. Subjek perokok yang dipilih termasuk kategori perokok ringan dan merokok $>1$ tahun.

\section{Pengambilan sampel}

Masing-masing subjek perokok dan bukan perokok diberi larutan garam fisiologis 0,9\% steril dan botol penampung steril yang telah diberi label. Subjek diminta berkumur dengan larutan garam fisiologis $0,9 \%$ steril sebanyak $10 \mathrm{~mL} \pm 30$ detik, kemudian air kumur dimasukkan kedalam botol sampel. Sampel dibawa ke laboratorium untuk dikultur dalam waktu kurang dari 2 jam (Rahman et al., 2015).

\section{Isolasi dan Purifikasi bakteri}

Sampel air kumur diambil dengan mikropipet sebanyak $100 \mu \mathrm{L}$ dan dituang ke atas masing-masing media MSA dan MC (2 ulangan), kemudian disebar merata menggunakan Drigalski. Seluruh cawan petri diinkubasi pada suhu $37^{\circ} \mathrm{C}$ selama $2 \times 24$ jam (Rahman et al., 2015). Setiap koloni yang tumbuh dan menunjukkan ciri koloni berbeda diambil dengan ose dan diinokulasikan kedalam media steril baru untuk memperoleh koloni murni. 


\section{Identifikasi isolat bakteri}

Isolat diidentifikasi secara makroskopis dengan melihat ciri koloni, mikroskopis dengan pewarnaan Gram dan uji reaksi biokimia yang meliputi uji katalase, uji koagulase, uji hemolisa pada agar darah, uji pada TSIA, SIM, Simmon's Citrate, dan uji fermentasi gula-gula. Identifikasi bakteri dilakukan dengan mencocokkan hasil uji dengan karakter bakteri pada buku Bergey's Mannual of Determinative Bacteriology (Holt et al., 1994).

\section{HASIL DAN PEMBAHASAN}

Isolasi terhadap cairan berkumur dari 10 orang responden perokok dan 10 orang responden bukan perokok pada 2 jenis media yaitu MacConkey (MC) agar dan Mannitol Salt Agar (MSA) diperoleh koloni-koloni bakteri dengan karakteristik morfologi sebagai berikut:

Table 1. Karakteristik morfologi koloni bakteri

\begin{tabular}{|c|c|c|c|c|c|c|c|}
\hline \multirow[t]{2}{*}{ Media } & \multicolumn{6}{|c|}{ Ciri Koloni Bakteri } & \multirow{2}{*}{$\begin{array}{l}\text { Kode } \\
\text { isolat }\end{array}$} \\
\hline & Warna & Tepi & Elevasi & Densitas & $\begin{array}{c}\text { Konsis } \\
\text { tensi }\end{array}$ & Sifat & \\
\hline \multirow[t]{3}{*}{ MSA } & Kuning & Halus & Cembung & Opak & Creamy & MF & RM1 \\
\hline & Putih & Halus & Cembung & Opak & Creamy & NMF & RM2 \\
\hline & Putih & Halus & Naik & Translucent & Creamy & NMF & RM3 \\
\hline \multirow[t]{6}{*}{ MC } & Merah & $\begin{array}{c}\text { Tidak } \\
\text { beraturan }\end{array}$ & Datar & Opak & Kering & $\mathrm{LF}$ & RM4 \\
\hline & Pink pucat & $\begin{array}{c}\text { Tidak } \\
\text { beraturan }\end{array}$ & Naik & Translucent & Berkerut & NLF & RM5 \\
\hline & Pink & Halus & Cembung & Opak & Berlendir & $\mathrm{LF}$ & RM6 \\
\hline & Pink & Halus & Cembung & Opak & Berlendir & $\mathrm{LF}$ & RM7 \\
\hline & Pink pucat & Halus & Naik & Translucent & Creamy & NLF & RM8 \\
\hline & Tidak berwarna & Halus & Datar & Translucent & creamy & NLF & RM9 \\
\hline
\end{tabular}

Ket: MF: Mannitol Fermenter; NMF: Non-Mannitol Fermenter; LF: Lactose Fermenter; NLF: Non-Lactose Fermenter

Pengamatan terhadap koloni-koloni bakteri yang tumbuh pada media MSA dari 10 sampel perokok dan 10 sampel bukan perokok diperoleh 3 jenis koloni yang menunjukkan ciri berbeda yaitu koloni berwarna kuning opak, koloni putih opak dan koloni putih translucent. Koloni berwarna kuning (RM1) disertai dengan perubahan warna media MSA dari pink menjadi kuning menunjukkan bahwa bakteri tersebut mampu memfermentasi manitol/Mannitol Fermenter (MF). Koloni putih opak (RM2) dan putih translucent (RM3) tidak menunjukkan perubahan warna pada media atau bersifat Non-Mannitol Fermenter (NMF).

Isolasi pada media MC dari 10 sampel perokok dan 10 sampel bukan perokok ditemukan 6 jenis koloni bakteri dengan morfologi berbeda. Tiga koloni bersifat Lactose Fermenter (LF) ditandai dengan warna koloni merah atau merah muda (RM4, RM6, RM7), dan 3 koloni lainnya 
(RM5, RM8, RM9) bersifat Non-Lactose Fermenter (NLF) ditandai dengan koloni yang berwarna pink pucat atau tidak berwarna. Isolat-isolat bakteri yang telah berhasil diisolasi kemudian diuji dengan pewarnaan Gram, dan uji reaksi biokimia.

Tabel 2. Hasil Uji Reaksi Biokimia Isolat Bakteri

\begin{tabular}{|c|c|c|c|c|c|c|c|c|c|}
\hline \multirow[t]{2}{*}{ Jenis Uji } & \multicolumn{9}{|c|}{ Hasil Uji Reaksi Biokimia Isolat Bakteri } \\
\hline & RM1 & RM2 & RM3 & RM4 & RM5 & RM6 & RM7 & RM8 & RM9 \\
\hline Bentuk sel & Kokus & Kokus & Kokus & $\begin{array}{l}\text { Koko } \\
\text { basil }\end{array}$ & $\begin{array}{l}\text { Koko } \\
\text { basil }\end{array}$ & Basil & Basil & $\begin{array}{l}\text { Koko } \\
\text { basil }\end{array}$ & Basil \\
\hline Susunan & Cluster & Cluster & $\begin{array}{l}\text { Pairl } \\
\text { chain }\end{array}$ & Single & Single & Single & Single & Single & Single \\
\hline Gram & + & + & + & - & - & - & - & - & - \\
\hline Katalase & + & + & - & - & + & + & + & + & + \\
\hline Koagulase & + & - & & & & & & & \\
\hline Hemolysis & $\beta$ & - & & & & & & & \\
\hline TSI & A/A & $\mathrm{A} / \mathrm{A}$ & $\mathrm{K} / \mathrm{A}$ & A/A & $\mathrm{A} / \mathrm{A}$ & $\mathrm{A} / \mathrm{Ag}$ & $\mathrm{A} / \mathrm{Ag}$ & $\mathrm{K} / \mathrm{NC}$ & $\mathrm{K} / \mathrm{K}$ \\
\hline $\mathrm{H}_{2} \mathrm{~S}$ & - & - & - & - & - & - & - & - & - \\
\hline Indol & - & - & - & - & - & - & + & - & - \\
\hline Motilitas & - & - & - & - & - & - & + & - & + \\
\hline $\begin{array}{l}\text { Simmon } \\
\text { citrat }\end{array}$ & - & - & - & - & - & + & + & - & + \\
\hline \multicolumn{10}{|l|}{ Fermentasi: } \\
\hline Glukosa & + & + & + & - & + & $+\mathrm{g}$ & $+\mathrm{g}$ & - & - \\
\hline Sukrosa & + & + & + & - & + & $+g$ & $+\mathrm{g}$ & - & - \\
\hline Laktosa & + & + & + & - & + & $+g$ & $+g$ & - & - \\
\hline Maltosa & + & $\mathrm{V}$ & - & - & + & $+g$ & $+g$ & - & - \\
\hline Mannitol & + & - & - & - & - & $+g$ & $+\mathrm{g}$ & - & - \\
\hline
\end{tabular}

Ket: +: postif, -: negatif; +g: Positif dengan gas; A/A: lereng kuning, dasar kuning; A/Ag: lereng kuning, dasar kuning, gas positif; K/NC: lereng merah, dasar tidak berubah; V: hasil uji bervariasi

Berdasarkan hasil pengamatan morfologi koloni (Tabel 1) dan pengamatan sel bakteri dan sifat Gram serta karakter biokimiawinya (Tabel 2), bakteri dengan isolat RM 1 memiliki kesamaan karakteristik dengan bakteri Staphylococcus aureus yaitu koloni berwarna kuning dan memfermentasikan mannitol pada media MSA, kokus gram positif tersusun bergerombol, memberikan reaksi katalase positif, koagulase positif dan membentuk hemolisa tipe beta pada agar darah. Oleh karena itu isolat RM1 diidentifikasi sebagai S. aureus. Isolat RM2 memiliki ciri sel dan hasil reaksi biokimia yang hampir sama dengan isolat RM1, perbedaannya adalah isolat RM2 tidak memfermentasi Mannitol, dan memberikan hasil negatif pada uji koagulase, sehingga isolat ini diidentifikasi sebagai kelompok Coagulase Negative Staphylococcus.

Isolat RM3 menunjukkan ciri sel kokus gram positif tersusun secara berpasangan dan berantai pendek, serta katalase negatif. Ciri tersebut adalah ciri yang dimiliki oleh bakteri Streptococcus. Namun bakteri Streptococcus tidak dapat tumbuh pada media yang mengandung kadar garam tinggi seperti MSA. Kelompok Streptococcus yang mampu tumbuh pada kondisi 
kadar garam tinggi adalah Enterococcus sehingga isolat RM3 diidentifikasi sebagai Enterococcus sp.

Lima isolat yang diperoleh dari pertumbuhan pada media MC agar menunjukkan bahwa isolat RM4, RM5, dan RM8 adalah bakteri gram negatif berbentuk kokobasil sedangkan isolat RM6, RM7, dan RM9 berbentuk basil. Isolat RM4 dan RM5 memiliki kemampuan tumbuh yang kurang baik pada medium MC. Kedua isolat ini tumbuh lambat dan membutuhkan waktu lebih dari 24 jam untuk membentuk koloni yang tampak. Ciri tersebut menunjukkan kedua isolat ini diduga adalah kelompok Fastidious Gram negatif Bacilli. Isolat RM4 memiliki karakteristik koloni kecil berwarna merah dan kering pada media MC tetapi hasil uji reaksi biokimia menunjukkan isolat ini bersifat inaktif atau tidak memberikan reaksi, sehingga isolat ini tidak dapat diidentifikasi. Isolat RM5 memiliki karakteristik koloni yang berkerut, bersifat non motil, tidak menggunakan sitrat, memfermentasi glukosa, laktosa, sukrosa, maltose, dan tidak memfermentasi mannitol. Karakter yang dimiliki isolat RM5 dimiliki oleh bakteri Aggregatibacter sp.

Hasil uji RBK isolat RM6 dan RM7 memiliki banyak kesamaan yaitu koloni pink berlendir, Lactose Fermenter, katalase positif, sitrat positif dan memfermentasi gula-gula uji disertai pembentukan gas $(+\mathrm{G})$. Perbedaan kedua isolat tersebut terletak pada motilitas, dimana bakteri RM6 bersifat nonmotil sehingga dikelompokkan kedalam anggota genus Klebsiella sedangkan isolat RM7 bersifat motil sehingga dikelompokkan kedalam anggota genus Citrobacter.

Isolat RM8 dan RM9 menunjukkan bakteri ini adalah bakteri berbentuk kokobasil gram negatif dan bersifat tidak memfermentasi gula-gula uji sehingga kedua isolat ini dikelompokkan sebagai Nonfermenting Gram Negatif Bacilli. Karakteristik isolat RM8 yang memberikan hasil negatif pada semua uji RBK merupakan karakteristik yang mirip dengan bakteri Acinetobacter. Isolat RM9 memberikan hasil K/K pada uji TSIA, motil, mampu menggunakan sitrat sebagai sumber karbon tunggalnya, dan tidak memfermentasi semua gula uji. Berdasarkan karakteristik tersebut isolat RM9 dikelompokkan kedalam anggota genus Pseudomonas.

Hasil identifikasi bakteri rongga mulut pada penelitian ini (Tabel 3) ditemukan 9 jenis bakteri yaitu bakteri S. aureus, Coagulase Negative Staphylococcus, Enterococcus sp., Aggregatibacter sp., Klebsiella sp., Citrobacter sp., Acinetobacter sp., Pseudomonas sp. dan isolat yang tidak teridentifikasi jenisnya (Unidentified species). Jumlah bakteri yang ditemukan pada rongga mulut perokok cenderung lebih banyak dari pada orang yang tidak merokok. Pada rongga mulut 10 orang perokok dijumpai 37 isolat bakteri yang terdiri dari 8 genus bakteri, sedangkan pada rongga mulut 10 orang bukan perokok dijumpai 26 isolat bakteri yang terdiri dari 8 genus bakteri. 
Tabel 3. Persentase kehadiran bakteri pada rongga mulut perokok dan bukan perokok

\begin{tabular}{llcccc}
\hline \multicolumn{1}{c}{ Kelompok } & \multicolumn{1}{c}{ Genus } & \multicolumn{2}{c}{ Perokok } & \multicolumn{2}{c}{ Bukan Perokok } \\
\cline { 3 - 6 } & & $\mathbf{N}$ & $\mathbf{\%}$ & $\mathbf{N}$ & $\mathbf{\%}$ \\
\hline Staphylococcaceae & Staphylococcus aureus & 2 & 5,41 & 1 & 3,85 \\
& $\begin{array}{l}\text { Coagulase Negative } \\
\text { Staphylococcus }\end{array}$ & 10 & 27,03 & 8 & 30,77 \\
Streptococcaceae & Enterococcus $\mathrm{sp}$ & 4 & 10,81 & 1 & 3,85 \\
HACEK Group & $\begin{array}{l}\text { Aggregatibacter } \mathrm{sp} \\
\text { Unidentified } \mathrm{sp}\end{array}$ & 8 & 21,62 & 1 & 3,85 \\
Enterobacteriaceae & Klebsiella $\mathrm{sp}$ & 4 & 10,81 & 0 & 0 \\
& Citrobacter $\mathrm{sp}$ & 4 & 10,81 & 5 & 19,23 \\
Nonfermenting Gram & Acinetobacter $\mathrm{sp}$ & 0 & 0 & 1 & 3,85 \\
Negative Bacilli & & 3 & 8,11 & 2 & 7,69 \\
& Pseudomonas $\mathrm{sp}$ & 2 & 5,41 & 7 & 26,92 \\
\hline Total Isolat & & $\mathbf{3 7}$ & $\mathbf{1 0 0}$ & $\mathbf{2 6}$ & $\mathbf{1 0 0}$ \\
\hline
\end{tabular}

Ket : $\mathrm{N}=$ Jumlah isolat yang ditemukan

Bakteri yang sering ditemukan pada rongga mulut perokok adalah bakteri Coagulase Negative Staphylococcus (27,03\%), dan Aggregatibacter sp. (21,62\%), sedangkan bakteri yang sering dijumpai pada rongga mulut bukan perokok adalah Coagulase Negative Staphylococcus (30,77\%), Pseudomonas sp. (26,92\%), dan Klebsiella sp. (19,23\%). Hasil yang diperoleh pada penelitian ini mirip dengan hasil penelitian (Ogba et al., 2017) yang dilakukan terhadap 60 orang perokok dan 60 orang bukan perokok yang menunjukkan bahwa jumlah bakteri pada perokok lebih tinggi $(86,7 \%)$ dibanding bukan perokok $(33,3 \%)$. Bakteri yang paling sering ditemukan pada perokok adalah S. aureus (25\%) dan Klebsiella pneumonia $(19,2 \%)$, sedangkan pada bukan perokok paling sering dijumpai bakteri Klebsiella pneumonia (20\%) dan Pseudomonas aeruginosa (20\%).

Pada penelitian ini bakteri Staphylococcus yang paling banyak dijumpai baik pada perokok maupun bukan perokok adalah kelompok Coagulase Negative Staphylococcus (CoNS), sedangkan S. aureus hanya dijumpai pada 2 orang perokok dan 1 orang bukan perokok. CoNS adalah bakteri yang biasanya tumbuh pada kulit dan membran mukosa pada tubuh manusia. Spesies yang termasuk kelompok CoNS adalah S. epidermidis, $S$. saprophyticus, $S$. haemolyticus, dan S. lugdunensis. Karena bakteri CoNS bersifat dapat mengkolonisasi berbagai bagian tubuh, bakteri ini sering ditemukan sebagai kontaminan pada berbagai specimen klinis (Mahon, Lehman and Manuselis, 2015).

Perbedaan yang signifikan tampak pada adanya bakteri Aggregatibacter sp. yang berhasil diisolasi dari 8 orang perokok (80\% perokok) tetapi hanya dijumpai pada 1 orang $(10 \%)$ bukan perokok. Bakteri Aggregatibacter sp. merupakan bakteri yang sebelumnya termasuk anggota genus Haemophillus, namun Aggregatibacter sp. tidak membutuhkan factor X dan 
factor V untuk mendukung pertumbuhannya seperti Haemophillus lainnya, sehingga bakteri ini dikelompokkan dalam genus baru. Bakteri Aggregatibacter adalah anggota HACEK Group yang pada dasarnya merupakan bakteri flora normal pada rongga mulut. Bakteri ini tumbuh dengan lebih baik pada lingkungan yang banyak mengandung $\mathrm{CO}_{2}$ (Mahon, Lehman and Manuselis, 2015). Karbon dioksida adalah salah satu zat yang terkandung pada fase gas asap rokok (U.S. Department of Health and Human Services, 2010). Berdasarkan data kuesioner, 70\% perokok menghisap >10 batang rokok per hari sehingga memungkinkan terjadinya peningkatan kadar $\mathrm{CO}_{2}$ di dalam rongga mulutnya dan hal tersebut yang kemungkinan menyebabkan tingginya jumlah bakteri Aggregatibacter pada perokok.

Pada penelitian ini juga ditemukan adanya bakteri-bakteri yang bukan merupakan flora normal pada rongga mulut seperti S. aureus, Acinetobacter, Enterococcus, Klebsiella, dan Pseudomonas. Keberadaan bakteri yang bukan merupakan bagian dari mikroflora normal pada rongga mulut dapat dimungkinkan berasal dari bahan-bahan yang terkontaminasi yang masuk ke dalam mulut seperti rokok, makanan, minuman, sikat gigi, dan lain-lain. Hasil penelitian (Sapkota, Berger and Vogel, 2010) menemukan bahwa dari 20 pak sampel rokok yang diuji, $\geq$ 90\% sampel terdeteksi adanya bakteri Acinetobacter, Bacillus, Klebsiella, Clostridium dan Pseudomonas. Hasil penelitian tersebut menunjukkan bahwa kebiasaaan merokok dapat mempengaruhi diversitas mikroba pada rongga mulut seseorang.

Perubahan diversitas mikroba rongga mulut pada perokok diantaranya disebabkan karena pengikatan sel-sel bakteri terhadap sel-sel epitel rongga mulut perokok lebih mudah terjadi (Brook, 2011). Bakteri menjadi lebih mudah melekat pada sel-sel epitel rongga mulut perokok sebab merokok dapat meningkatkan produksi mukus, merusak sifat elastis sel-sel epitel, menurunkan produksi IgA, dan mempengaruhi aktivitas fagositosis. Perubahan-perubahan tersebut memfasilitasi kolonisasi bakteri dan memperburuk respon inflamasi yang mengarah pada kerusakan sel-sel epitel, hingga merusak imunitas inang dan meningkatkan kolonisasi bakteri. Pada akhirnya, paparan asap rokok baik secara langsung maupun tidak langsung mengubah komposisi mikroba dengan membuka jalan masuk bagi bakteri patogen oportunistik seperti (Garmendia, Morey and Bengoechea, 2012). Penelitian (Yetkin et al., 2010) juga menemukan adanya bakteri patogen pada perokok diantaranya $S$. aureus, $N$. meningitides, Acinetobacter lwofii, E. coli, Haemophilus aphrophilus dan $\beta$-hemolitik Streptococcus. Peningkatan jumlah bakteri patogen ini terjadi pada 24 dari 57 orang perokok (43\%), sedangkan pada bukan perokok hanya ditemukan pada 4 dari 20 orang (20\%). Berdasarkan kategori perokok, bakteri pathogen ditemukan pada $20 \%$ perokok ringan, $50 \%$ perokok sedang, dan $83 \%$ perokok berat. 
Namun menurut hasil penelitian (Wu et al., 2016) perubahan flora rongga mulut perokok bersifat tidak permanen, yang berarti bahwa kelimpahan bakteri pada rongga mulut dapat kembali menjadi normal ketika seseorang tidak lagi atau telah berhenti merokok. Charlson et al juga menyebutkan bahwa kebiasaan merokok dapat meningkatkan jumlah bakteri penyebab periodontitis seperti Parvimonas, Fusobacterium, Bacteroides, Prophyromonas, dan Campylobacter. Namun pada seseorang yang telah berhenti merokok, komunitas bakteri rongga mulut akan mengalami repopulasi dan peningkatan jumlah bakteri baik, serta diikuti dengan penurunan jumlah bakteri pathogen (Charlson et al., 2010).

Penelitian-penelitian mengenai jenis-jenis bakteri pada rongga mulut perokok dan bukan perokok yang telah dilakukan sebelumnya menunjukkan hasil kelimpahan dan jenis bakteri yang berbeda-beda (Charlson et al., 2010; Kumar et al., 2011; Morris et al., 2013) . Perbedaan jenisjenis bakteri yang ditemukan ini kemungkinan dapat disebabkan karena jumlah sampel yang terlalu sedikit, area pengambilan sampel yang berbeda pada rongga mulut, dan perbedaan dalam metodologi pengujian di laboratorium, dimana beberapa diantaranya menyebabkan keterbatasan dalam menggambarkan profil bakteri (Wu et al., 2016)

\section{SIMPULAN}

Berdasarkan hasil penelitian yang diperoleh maka dapat disimpulkan bahwa rongga mulut perokok memiliki jumlah bakteri yang lebih banyak dari pada bukan perokok. Pada rongga mulut perokok bakteri yang sering ditemukan adalah Coagulase negative Staphylococcus (27,03\%), dan Aggregatibacter sp. (21,62\%), sedangkan pada rongga mulut bukan perokok lebih sering dijumpai bakteri Coagulase Negative Staphylococcus (30,77\%), Pseudomonas sp. (26,92\%), dan Klebsiella sp. (19,23\%).

\section{UCAPAN TERIMA KASIH}

Ucapan terima kasih peneliti sampaikan kepada Yayasan John Paul II Pekanbaru yang telah memberikan bantuan dana penelitian dan pihak-pihak yang telah berkenan menjadi pratisipan untuk membantu dan bekerjasama demi kelancaran penelitian ini.

\section{DAFTAR PUSTAKA}

Arweiler, N.B. and Netuschil, L., 2016. The Oral Microbiota. In: Microbiota of the Human Body. Switzerland: Springer International Publishing.pp.45-60.

Brook, I., 2011. The impact of smoking on oral and nasopharyngeal bacterial flora. Journal of Dental Research, 90(6), pp.704-710. 
Charlson, E.S., Chen, J., Custers-Allen, R., Bittinger, K., Li, H., Sinha, R., Hwang, J., Bushman, F.D. and Collman, R.G., 2010. Disordered microbial communities in the upper respiratory tract of cigarette smokers. PLoS ONE, 5(12), pp.1-10.

Dewhirst, F.E., Chen, T., Izard, J., Paster, B.J., Tanner, A.C.R., Yu, W., Lakshmanan, A. and Wade, W.G., 2010. The Human Oral Microbiome. Journal of Bacteriology, 192(19), pp.5002-5017.

Fitri, H. and Hidayati, 2012. Hubungan Kebiasaan Merokok Dengan Penyakit Periodontal Karyawan PT . Family Raya Gurun Laweh. Andalas Dental Journal, [online] pp.113-116. Available at: 〈http://adj.fkg.unand.ac.id/index.php/adj/article/download/25/pdf〉.

Garmendia, J., Morey, P. and Bengoechea, J.A., 2012. Impact of cigarette smoke exposure on host-bacterial pathogen interactions. European Respiratory Journal, 39(2), pp.467-477.

Holt, J.G., Krieg, N.R., Sneath, P.H.A., Staley, J.T. and Williams, S.T., 1994. Bergey'S Manual of Determinative Bacteriology 9Th Edition. USA: Williams \& Wilkins.

Kumar, P.S., Matthews, C.R., Joshi, V., de Jager, M. and Aspiras, M., 2011. Tobacco smoking affects bacterial acquisition and colonization in oral biofilms. Infection and Immunity, 79(11), pp.4730-4738.

Mahon, C.R., Lehman, D.. and Manuselis, G., 2015. A Textbook of Diagnostic Microbiology. Fifth Edit ed. SpringerVerlag Berlin Heidelberg. Missouri: ELSEVIER.

Morris, A., Beck, J.M., Schloss, P.D., Campbell, T.B., Crothers, K., Curtis, J.L., Flores, S.C., Fontenot, A.P., Ghedin, E., Huang, L., Jablonski, K., Kleerup, E., Lynch, S. V., Sodergren, E., Twigg, H., Young, V.B., Bassis, C.M., Venkataraman, A., Schmidt, T.M. and Weinstock, G.M., 2013. Comparison of the respiratory microbiome in healthy nonsmokers and smokers. American Journal of Respiratory and Critical Care Medicine, 187(10), pp.1067-1075.

Ogba, O.M., Ewa, J.J., Olorode, O.A. and Mbah, M., 2017. Effect of Tobacco Smoking on Oral Microbial Flora and the Relationship with Oral Health in Calabar, Nigeria. International Journal of Biomedical Laboratory Science (IJBLS), [online] 6(2), pp.1-5. Available at: <http://www.ijbls.org/upfile/Issues/201818172045.pdf〉.

Rahman, M., Islam, N., Islam, M.N. and Hossain, M.S., 2015. Isolation and Identification of Oral Bacteria and Characterization for Bacteriocin Production and Antimicrobial Sensitivity. J. Pharm. Sci, 14(1), pp.103-109.

Sapkota, A.R., Berger, S. and Vogel, T.M., 2010. Human pathogens abundant in the bacterial metagenome of cigarettes. Environmental Health Perspectives, 118(3), pp.351-356.

U.S. Department of Health and Human Services, 2010. How Tobacco Smoke Causes Disease: The Biology and Behavioral Basis for Smoking-Attributable Disease: A Report of the Surgeon General. United States: Office of the Surgeon General.

Warnakulasuriya, S., Dietrich, T., Bornstein, M.M., Peidró, E.C., Preshaw, P.M., Walter, C., Wennström, J.L. and Bergström, J., 2010. Oral health risks of tobacco use and effects of cessation Saman. International Dental Journal, 60(1), pp.7-30. 
WHO, 2011. Global Adult Tobacco Survey: Indonesia Report 2011. Indonesia.

Wu, J., Peters, B.A., Dominianni, C., Zhang, Y., Pei, Z., Yang, L., Ma, Y., Purdue, M.P., Jacobs, E.J., Gapstur, S.M., Li, H., Alekseyenko, A. V., Hayes, R.B. and Ahn, J., 2016. Cigarette smoking and the oral microbiome in a large study of American adults. ISME Journal, [online] 10(10), pp.2435-2446. Available at: 〈http://dx.doi.org/10.1038/ismej.2016.37〉.

Yetkin, G., Ay, S., Yetkin, Ö., Taptekin, N. and Güçlüer, N., 2010. Sigara İçiminin Nazofarinks de Potansiyel Patojenlerin Taşiyiciliğina Etkisi. Erciyes Medical Journal, 32(1), pp.9-14.

Yu, G., Phillips, S., Gail, M.H., Goedert, J.J., Humphrys, M.S., Ravel, J., Ren, Y. and Caporaso, N.E., 2017. The effect of cigarette smoking on the oral and nasal microbiota. Microbiome, [online] 5(1), pp.1-6. Available at: 〈http://dx.doi.org/10.1186/s40168-016-0226-6>. 